\title{
Literacy and reward: teachers' effort to build children reading habit
}

\author{
Komang Widia Helena Arisandi ${ }^{1, *}$, Ni Nyoman Padmadewi ${ }^{1}$, Luh Putu Artini ${ }^{1}$ \\ ${ }^{1}$ English Education Department, Universitas Pendidikan Ganesha, 81116 Singaraja-Bali, Indonesia
}

\begin{abstract}
Children at early levels of primary school require appropriate guidance in their initial reading skill. They need to be trained on how reading becomes an enjoyable routine activity. This study aimed at describing teachers' effort to build children reading habit. This study employed a qualitative descriptive study and conducted at North Bali Bilingual School Bali. The data were collected through observations and interview. The findings of the study showed that there were several activities conducted by the teacher as efforts to build children reading habit. In terms of building students' reading habit, the teacher used (1) Point-written in Reading Rocket Chart (PRRC), (2) Chip (white, yellow, green) for appreciating good behaviour in reading and using English, (3) Certificate, (4) Class Reward, and (5) Free Play Time. With these efforts, it is evident that the students' literacy improves and they exhibited great enthusiasm in their reading and studying literacy in the classroom. Keywords: Literacy, Reward, Reading Habit
\end{abstract}

\section{Introduction}

Literacy is the foundation which is very important in children's life. Literacy is said as the key to enhance human capabilities which involved the ability in reading and writing [1, 2]. The intention of people write and read is to construct meaning [3-5]. According to [6] in English literacy, students are not only expected to be able to read, but also afford to communicate fluently, independently, and effectively in the society.

National phenomenon today shows that the literacy skills of Indonesian children are very low compared with children in other countries. It will be related to the role of parent as well as teacher. Based on the result of study conducted by [7], English teachers need to increase their knowledge and experience in understanding the concept for using the strategies to teach reading. They should have awareness to the significance in choosing the appropriate strategies for teaching reading. Besides, the results of PISA (the Programme for International Student Assessment) are less satisfactory. In 2015, the average value of reading is 397 in the rank of $62^{\text {nd }}$ of 70 countries that took part in the PISA 2015 [8].

Reading allows children to learn and gain knowledge which is an important gateway to personal development [9]. It is capable in increasing and improving children insight in their early progress. Accordingly, the real efforts how to introduce literacy especially in reading

* Corresponding author: elen_arisandi@rocketmail.com 
skill is very necessary. Several attempts have been made nationally, such as: building a library in every school and even the government always provide assistance in the form of books. However these solutions do not have the maximum impact. Reading is still at the level of carrying out the instruction. Most of the students do not have a character in case of loving to read. Most of them perform reading activities for the teacher's instructions, because the demands of the task, the repetition or exams, and have not shown their initiative intrinsically or because of his own desire to go to the library to read. In this regard, it extremely needs a teacher role. This research aimed at describing teachers' effort to build children reading habit. For this purpose, whether there is a significant effort that has to be done by the teacher in terms of students' reading habit.

\section{Method}

\subsection{Subject of Study}

The subject of this study was the students of North Bali Bilingual School. The students in grade 1,2 and 3 were selected as the subject of this study. Besides, the teacher and headmaster were also as the subjects who were observed by the researcher. They were also as informants in gaining the data through interviewing.

\subsection{Instruments}

In this study, there were several types of instruments used by the researcher in collecting data. They are human instrument, observation checklist, and interview guide. Human instrument was used as the key instrument of qualitative research. The researcher used checklist during the observation to write down the interesting and important information during the process of collecting data. After conducting classroom observation, the interview was conducted by the researcher toward the learning process. Besides, the interview was used to investigate kinds of rewards used in which may influence students' reading habit.

\subsection{Procedures of data collection}

In eliciting the objectives of this research, the procedures of data collection were designed. The first step was done by observing the students in grade 1, 2 and 3 in North Bali Bilingual School. To explore back the result of observation, the interview was carried out as well. It aimed at eliciting related information from the teacher and also the headmaster about how reading activity was done by the students properly. Besides, the teacher's teaching method and guiding the students were much needed which may bring influences on their reading habit. Then, the data regarding to the teacher effort by giving rewards to build students' reading habit was gained from the observation and interview.

\subsection{Data analysis}

The data were analyzed to discuss the teacher's effort to build children reading habit through rewards. This study employed a qualitative descriptive study and conducted at North Bali Bilingual School Bali. [10] suggest that qualitative data analysis consists of three procedures; Data Reduction, Data Display and Conclusion Drawing/Verification. 


\section{Results and Discussion}

The findings of the study showed that there were several activities conducted by the teacher as efforts to build children reading habit. In terms of building students' reading habit, the teacher used (1) Point-written in Reading Rocket Chart (PRRC), (2) Chip (white, yellow, green) for appreciating good behaviour in reading and using English, (3) Certificate, (4) Class Reward, and (5) Free Play Time.

Table 1. Reward Application and Students' Response toward Reading Rewards

\begin{tabular}{|c|c|c|c|}
\hline $\begin{array}{l}\text { Name of } \\
\text { Rewards }\end{array}$ & $\begin{array}{c}\text { When Reward is } \\
\text { Given }\end{array}$ & The Reward & Students' Response \\
\hline $\begin{array}{l}\text { Point-written in } \\
\text { Reading Rocket } \\
\text { Chart (PRRC) }\end{array}$ & $\begin{array}{l}-10 \text { minutes reading }= \\
1 \text { point } \\
-21 \text { minutes reading }= \\
3 \text { points }\end{array}$ & $\begin{array}{l}\text { - Enjoying in the } \\
\text { reading corner }\end{array}$ & $\begin{array}{l}\text { - Students were excited } \\
\text { in achieving points by } \\
\text { reading every day }\end{array}$ \\
\hline $\begin{array}{l}\text { Chip (white, } \\
\text { yellow, green) }\end{array}$ & $\begin{array}{l}\text { - White = using } \\
\text { English } \\
\text { - Yellow = good } \\
\text { attitude in society } \\
\text { - Green = enthusiastic } \\
\text { in reading and writing }\end{array}$ & - Chip collection & $\begin{array}{l}\text { - Students were } \\
\text { interested in collecting } \\
\text { the chips by doing a } \\
\text { positive behaviours in } \\
\text { school }\end{array}$ \\
\hline Certificate & $\begin{array}{l}\text { - } 15 \text { minutes reading } \\
\text { routinely }=\text { super } \\
\text { reader certificate }\end{array}$ & $\begin{array}{l}\text { - Super Reader } \\
\text { Certificate }\end{array}$ & $\begin{array}{l}\text { - Students had passion in } \\
\text { possessing the certificate } \\
\text { by striving to read } \\
\text { routinely and make } \\
\text { reading as their habit }\end{array}$ \\
\hline Class Reward & $\begin{array}{l}\text { - } 500 \text { points in a week } \\
=\text { class reward }\end{array}$ & $\begin{array}{l}\text { - } 10 \text { minutes free } \\
\text { time for playing }\end{array}$ & $\begin{array}{l}\text { - All students in a class } \\
\text { showed their cooperation } \\
\text { in collecting and } \\
\text { achieving the points by } \\
\text { reading every day }\end{array}$ \\
\hline Free Play Time & $\begin{array}{l}\text { - } 500 \text { points or more in } \\
\text { a week (accordance to } \\
\text { the teacher students } \\
\text { agreement) = free play } \\
\text { time }\end{array}$ & $\begin{array}{l}\text { - Playing in } \\
\text { classroom, } \\
\text { playground, and } \\
\text { creativity room. } \\
\text { - Free time for } \\
\text { watching film }\end{array}$ & $\begin{array}{l}\text { - Students were very } \\
\text { enthusiastic in following } \\
\text { the agreement, and } \\
\text { making reading as their } \\
\text { hobby }\end{array}$ \\
\hline
\end{tabular}

\subsection{Point-written in Reading Rocket Chart (PRRC)}

The Point-written in Reading Rocket Chart is one of the rewards given in North Bali Bilingual School in the early level of primary students. This reward is given when the students have read. Every 10 minutes reading is appreciated one point. The students who have not read, they give no point. Awarding the point depends on each teacher in NBBS. Every class can determine reading point differently. According to one of the teachers in that school, she checks students' point in every week. There are 5 rules in reading that she and her students mutually agreed. $1-10$ minutes reading is counted one point. $11-20$ minutes is counted two points. For 21 minutes of reading are counted three points. The students, 
who gain 3 points in every day, will have 5 points in a week. Every point will be collected and placed in the house owned by the student. The student who is able to be a super reader of the month (full reading by gaining 3 points for a month) is given gift by the teacher. Usually, the gift is enjoying in the reading corner.

\subsection{Chip (white, blue, and green) for Appreciating Good behaviour in Reading and Using English}

For the students in the early level, Chip is given by the teacher as a reward. The use of chip is used for appreciating the students' behaviours in reading. There are three colours of chip that provided by the teacher, such as: white, blue, and green. The white chip is used for motivating the students in using English. The blue chip is used for students' attitude in their society inside or outside classroom. Meanwhile, the green chip is used for the students' learning attitude. The students who are enthusiastic in reading and writing practice will be given the green chip.

\subsection{Certificate}

The other reward is certificate. According to[11], the use of tangible reward like certificate is often utilized to increase reading. In NBBS, certificate is usually given for the super reader. Super reader is the name for the students who reading more than 15 minutes in every day throughout holiday. They will obtain 3 points in every reading. If the students read more than 15 minutes routinely, they will be given the Super Reader Certificate. It is given after long holiday in the middle of semester or the end of semester.

A study was conducted by [12] about rewards for reading in the level of elementary students. Based on the result on their research, after they control for pre-reward reading motivation, sex, and grade, and combined with the reward variables (intangible and tangible rewards (prizes of token, certificate, food), reward expectancy) significantly improved the prediction of post-reward intrinsic reading motivation, extrinsic reading motivation, and global reading motivation. From the result, it can be said that the use of certificate as a reward gives positive influence for students' reading habit.

\subsection{Class Reward}

The Class Reward is the reward given by the teacher who in charge in the class. It depends on the teacher what kind of rewards would be given to the students. Usually, the teacher gives free time as the reward. Every class has to have 500 points in a week. If the class successes in achieving the point, the students will obtain the free time as the reward from the teacher. The free time is usually given for 10 minutes for playing in the playground.

This reward has been applied by the teacher in NBBS. Teaching reading needs a big teacher's effort which cannot be separated from the technique used in the teaching process. A study was conducted by [6] in terms of technique of teaching reading for boosting English literacy for those who in the first grade of elementary school. The result has showed that there are two major reading techniques implemented such as phonic approach and the whole language approach in order to improve the students' English literacy. The two techniques are complimenting each other and found to be effective to improve the students' literacy not only in reading but also in speaking. The students are always happy and cheerful in the classroom because the approaches implemented bring joyful learning in the classroom. 


\subsection{Free Play Time}

Free Play Time is a reward given by teacher for the students who gain the point of reading which accordance with teacher-students agreement. This reward can be the additional time for playing in the classroom, playground or in the creativity room. It also can be a time for watching film. All of the free time are given depend on the teacher creativity.

\section{Conclusion}

Motivating the students to read leads to success outside of the classroom. The rewards above is given depend on the teacher who in charge in the class. The role of teacher can support students' reading habit by creating positive efforts, such as using point-written in reading rocket chart for appreciating the students in reading, using chip, certificate, class reward, and free play time. With these efforts, it is evident that the students' literacy improves and they exhibited great enthusiasm in their reading.

\section{References}

1. N. Burnet. Education for All: Literacy for Life. (Unescho Publishing, Paris, 2005)

2. T. Haryanti. Jambore Taman Bacaan Masayarakat. (2004)

3. G. Owocki. Make Way for Literacy. (Heinemann Porthsmouth, NH. Washington DC, 2001)

4. L. Morrow. Developing Literacy in Preschool. (The Guilford Prss, London, 2007)

5. SB. Neuman, KA. Roskos. Language and Literacy Learning in the Early Years. An Integrated Approach. (Harcout Brace Jovanovich College Publishers, United States America, 1993)

6. NN. Padmadewi, PNP. Sari, DAE. Agustini. JPBI. 1, 1 (2013)

7. LP. Artini, K. Seken, K. Ahmad. JPBI. 1, 1 (2013)

8. Indonesia PISA Centre. Hasil PISA 2012.

9. C. Clark, K. Rumbold. Nat. Li.t Trst. 5 (2006)

10. MB. Milles, AM. Huberman. Qualitative Data Analysis: Second Edition. (SAGE, London, 1994)

11. M. Anthuis. The Effect of Extrinsic Rewards and Intrinsic Motivation on Student Reading and Learning. 11. (2014)

12. PH. Chen, JR. Wu. JIP. 4 (2010) 